the dislocations and upheavals of the English Revolution, the history of their earlier deployments still remains tantalizingly unexplored.

MARK ALBERT JOHNSTON, University of Windsor

\title{
Landi, Sandro.
}

\section{Stampa, censura e opinione pubblica in età moderna.}

Bologna : Il Mulino, 2011, 168 pages, ISBN 978-88-15-23391-2 (broché) 11,50€.

Même s'il ne concerne que partiellement, et de biais, les études consacrées à l'Humanisme, la Renaissance et la Réforme, le petit livre de Sandro Landi portant sur l'édition, la censure et l'opinion publique à l'époque moderne mérite d'être signalé. Il constitue en effet une excellente synthèse critique sur l'histoire du livre et de la communication dans leur relation avec l'histoire des idées politiques, qu'ordonne la question de la formation et du développement de l'opinion publique. Cette synthèse, rédigée dans une perspective essentiellement italienne, est d'autant plus intéressante et nécessaire qu'elle permet la rencontre de disciplines généralement séparées ou qui n’ont pas la même définition, ni surtout la même autorité, dans les différents systèmes académiques nationaux. Autant qu'à la référence aux travaux les plus récents (environ 300 titres), c'est à la dimension critique de l'entreprise que l'on sera le plus sensible, marquée par le souci d'examiner à de nouveaux frais des « lieux » du discours historique sur le livre, en les problématisant et en les périodisant.

On ne peut plus penser l'invention de l'imprimerie comme une coupure et une révolution dans une histoire de l'humanité, et la concevoir simplement en termes téléologiques de progrès. L'imprimerie a été un facteur déterminant, qui a permis l'amplification de transformations matérielles et intellectuelles déjà en œuvre dans la longue durée, portées par le livre manuscrit. Si l'époque moderne (c. 1450-1815) correspond à une phase bien définie du développement technique du livre imprimé, et si celui-ci donne également une identité particulière à l'Europe en tant que lieu exclusif de son développement (par opposition à un monde musulman marqué par un refus radical), dans le même temps, le processus de communication, même en Europe, n'est assumé que partiellement par l'imprimé. La reconstruction de la communication orale 
du passé comme la prise en compte de la publication manuscrite constituent des enjeux historiographiques majeurs pour la compréhension des formes anciennes des échanges sociaux. Enfin, la censure, toujours conçue en termes négatifs, comme un obstacle au progrès que permettrait la diffusion imprimée, constitue traditionnellement un objet privilégié de l'histoire du livre et d'une histoire intellectuelle fascinée par les hétérodoxies. Elle demande elle aussi à la fois à être réexaminée selon des données précises et périodisées, et surtout repensée en tant qu'objet d'histoire, représentation culturelle et lieu de mémoire de la tradition historiographique qui la fige en une instance répressive ; il convient ainsi de faire l'histoire de l'histoire de la censure, en tant que création idéologique, autant que l'histoire de la censure ou plutôt des différentes formes de censures. Celle-ci peut être précisée. L'acception courante, qui identifie censure et censure éditoriale, et qui privilégie, au sein de celle-ci la censure ecclésiastique, elle-même réduite à l'Index, est à la fois réductrice et souvent mythifiante. L'auteur rappelle qu'il n'est pas impropre de parler de «libertà di stampa» (qui ne se confond pas avec la seule liberté de presse), et ce, même dans les régions soumises aux contrôles les plus rigoureux, dans la mesure où le jeu de la concurrence entre les juridictions qui exerçaient la censure créait des espace de libre expression du discours. De surcroît, on rappellera que la censure a pu être utilisée par les auteurs eux-mêmes comme instance d'autorité : on pourra évoquer à ce propos les travaux d'Ugo Rozzo, mentionnés par l'auteur, comme les études de Bruno Neveu, les premiers à prendre en compte le point de vue du censeur, ou les découvertes récentes concernant l'examen des Essais de Montaigne par la censure romaine, en particulier les travaux d'Alain Legros, non mentionnés. En élargissant le cadre chronologique, l'histoire du livre en général et l'histoire de la censure en particulier contribuent à une meilleure connaissance de la naissance et du développement de l'opinion publique à l'époque moderne, devenue objet d'étude depuis une trentaine d'années. Des travaux récents ont mis en évidence les formes variées, les publics et les lieux d'exercice où se déploient dès le XVI e siècle, à Venise ou à Florence, les formes de communication politique qui révèlent comme autant d'opinions publiques. La définition canonique de celle-ci donnée par Habermas, comme «sphère publique bourgeoise », définissant un modèle abstrait hérité des Lumières, apparaît ainsi, à son tour, sans ancrage et sans précision historique, comme une construction idéologique inscrite dans son temps et répondant à des besoins particuliers. L'histoire du livre, en tant qu'histoire critique, apparaît comme un 
bon correctif aux abstractions de la philosophie politique, et le temps long, qui prend en considération la période de la Renaissance, une bonne manière de comprendre la modernité.

Jean balsamo, Université de Reims

\section{Low, Jennifer A. and Nova Myhill (eds.).}

Imagining the Audience in Early Modern Drama, 1558-1642.

New York: Palgrave Macmillan, 2011. Pp. ix, 218. ISBN 978-0-230-11064-9 (hardcover) \$85.

Low and Myhill's collection is eminently useful not just because it makes an important methodological contribution to early modern English theatre studies, but also because its organizational scheme makes a survey of scholarly opinion on its subject so easily accessible. Consequently, the book will be helpful to specialists in their teaching as well as in their research.

The volume's title, Imagining the Audience, names both the central methodological problem it addresses and the solution its editors and authors propose. Since there is so little surviving evidence of the interactions between audiences and performances in the early modern English theatre, scholars must work imaginatively with evidence of how the early modern theatre imagined audiences and audience members. This is a deft and satisfying move for two reasons. First, without ever shirking its responsibility to acknowledge external documentary evidence (which is amply provided in the volume), it releases theatre historians from some of the positivist anxiety that has plagued the field since the documentary turn championed by the Records of Early English Drama project: namely, the fear that in the absence of a demonstrably reliable and complete empirical record, we cannot say anything at all. Second, in relieving anxiety about the completeness of the historical record, it refocuses our attention on its meaning, which is, after all, why evidence matters in the first place. The reasons why interactions between early modern audiences and performances matter are multiple and varied, and Low and Myhill organize their collection to emphasize that complexity. After an introduction that frames their subject helpfully in the context of Keir Elam's theoretical work 